\title{
VI Did the Mysteries Influence Early Christianity?
}

After a run of rather depressing years, life was looking up for Rudolf Steiner (1861-1925) at the turn of the century. The later founder of anthroposophy had come into contact with a new kind of benefactor, Cay Lorenz Graf von Brockdorff (1844-1921), who had invited him to give regular lectures in his library. Steiner was only too happy to oblige, and from the $19^{\text {th }}$ of October 1901 to the $26^{\text {th }}$ of April 1902 he gave a weekly address to a mostly theosophical audience on the essence of Christianity and its place in the historical development of humanity. The lectures were immediately published under the title Das Christentum als mystische Tatsache und die Mysterien des Altertums. ${ }^{1}$ This small book allows us to see what in Germany, around 1900, an intellectual with esoteric interests thought of the influence of the Mysteries on early Christianity. The result of his study, to be honest and for some of my readers perhaps not wholly surprising, is not that encouraging.

Steiner began his lectures by explaining that the doctrine of the Greek Mysteries (Mysterienlehren) went back well into the eighth century BC, if not earlier, and had been enriched by the doctrines of the Egyptian, Persian and even Indian Mysteries. For Greece he did not begin with Eleusis but with Heraclitus, whom he made into an initiate of the Mysteries in his home town of Ephesus (3845). As we have seen (Ch. III.3), Heraclitus actually railed against local private Mysteries. It is thus immediately clear that Steiner was not a very good guide for his interested, but no doubt poorly informed audience. This impression is only confirmed by the rest of his lectures. Like many predecessors, Steiner paid much attention to the Egyptian Mysteries (97-110), which, as we saw (Ch. V.1), never existed, but he also - and this was more daring, though equally unconvincing stressed all kinds of parallels between the Buddha and Jesus (102-07). This Indological approach to Jesus, so to speak, had become popular in the later nineteenth century, as Buddhism gained in popularity amongst Germans looking for a new religion that could be reconciled with modern knowledge. Its absence of a transcendent sphere made Buddhism especially attractive in some circles as a source of new moral values, as still is the case today. ${ }^{2}$

1 R. Steiner, Das Christentum als mystische Tatsache und die Mysterien des Altertums (Berlin, $\left.1902,1910^{2}\right)=$ Rudolf Steiner Gesamtausgabe 8 (Dornach, 1989 ${ }^{9}$ ), cf. H. Zander, Rudolf Steiner (Munich and Zurich, 2011) 153-158. The numbers in the text refer to the pages of the second, revised edition.

2 Cf. S.L. Marchand, German Orientalism in the Age of Empire (Washington DC and Cambridge, 2009) 270-279; V. Hösle, 'The Search for the Orient in German Idealism', Zs. Deutsch. Morgenl. Gesellsch. 163 (2013) 431-454. 
When Steiner finally arrives at the Mysteries' influence on early Christianity we are in for a surprise. If I understand his somewhat obscure prose correctly, Steiner suggests that what the initiates once heard and saw in the Mysteries in the temples of Egypt was transformed into the historical Jesus. The cult drama of Osiris eventually produced the Jesus of the Gospels, in whose fate all Christians could now participate and in this way receive a share of the wisdom of the Mysteries, namely that the world was divine (105-07). The four authors of the Gospels thus derived their material from four different Mystery traditions (112), albeit, as I must stress, in mysterious ways, as Steiner does not explain how they reached their results. At this point, though, it is better to take temporary leave of Steiner. His book is obviously not the right guide in our labyrinth of Mysteries.

\section{The Mysteries around 1900 and during the Enlightenment}

Steiner's attention to the Mysteries was typical of the Zeitgeist in Germany in 1900. ${ }^{3}$ In particular, their relationship to emerging Christianity had become an important topic of debate. Both the growth in historical analysis of early Christianity, as exemplified by David Friedrich Strauss's (1808-1874) influential Das Leben Jesu, ${ }^{4}$ and the secularising trend in late nineteenth-century Germany had translated into attempts to derive early Christianity from its pagan surroundings. In other words, there was a hidden agenda here that was looking for support from antiquity for its own abandonment of the Christian Faith. That is why the more adventurous theologians, members of and sympathisers with the so-called Religionsgeschichtliche Schule of Göttingen, ${ }^{5}$ started to derive the apostle Paul's theology from a Mithras cult in Tarsus, ${ }^{6}$ his birthplace, even though no Mystery cult of Mithras is attested in Tarsus nor is any Mithras Mystery found anywhere before the end of the first century (Ch. V.2). ${ }^{7}$ Others even derived Christianity as a

3 For a good survey of the religious situation in Germany at that time, see T. Nipperdey, Religion im Umbruch: Deutschland 1870-1914 (Munich, 1988).

4 D.F. Strauss, Das Leben Jesu, kritisch bearbeitet, 2 vols (Tübingen, 1835-1836).

5 G. Lüdemann and M.Schröder, Die religionsgeschichtliche Schule in Göttingen (Göttingen, 1987); G. Lüdemann and A. Özen, 'Religionsgeschichtliche Schule', in TRE 28 (1997) 618-624; see also P. Gemeinhardt, 'Die Patristik um 1911 in ihrem Verhältnis zur Religionsgeschichte', Zs. Ant. Christ. 15 (2011) 75-98.

6 See, for example, A. Lannoy, 'St Paul in the early $20^{\text {th }}$ century history of religions. "The mystic of Tarsus" and the pagan mystery cults after the correspondence of Franz Cumont and Alfred Loisy', ZRGG 64 (2012) 222-239.

7 For the older discussions, see G. Lease, 'Mithraism and Christianity: Borrowings and Transformations', in ANRW 2.23.2 (1980) 1306-1332. The most recent treatments are M. Clauss, Mithras: 
whole from the Mystery religions, as they called the ancient Mysteries (see Preface). ${ }^{8}$ Meanwhile other, less adventurous theologians and more hard-headed ancient historians, such as Eduard Meyer (1855-1930), ${ }^{9}$ denied any influence from the surrounding religions except Judaism. The debates between these approaches helped to create an atmosphere in which both the study of the ancient Mysteries and the Leben-Jesu-Forschung flourished and which lasted until the 1920s, when they were superseded by new theological interests, such as those inspired by Karl Barth (1886-1968) and Rudolf Otto (1869-1937).

In addition to the influence of the secularising Zeitgeist, Steiner's book also displays a fascination with the Egyptian Mysteries that had been characteristic of Enlightenment scholars, who saw in ancient Egypt the mirror image of their own condition. Representing the Egyptian priests as living underground in caves and crypts where they performed their Mysteries, they had imagined them as occupying a position comparable to their own, as they were subject to censorship and often forced to publish illegally. ${ }^{10}$ They also took the supposed organisation of these priests as the model for the lodges of the Freemasons, Illuminati, Rosicrucians and other esoteric groups. ${ }^{11}$ The rise of such secret brotherhoods has had a powerful grip on the popular imagination ever since, as we have witnessed more recently in the astonishing success of Dan Brown's The Da Vinci Code ${ }^{12}$ just as we still derive enjoyment from this interest in esoteric Egypt through Mozart's Zauberflöte of 1791, as Jan Assmann has splendidly shown. ${ }^{13}$

Kult und Mysterium (Darmstadt and Mainz, 2012) 159-167 and 'Mithras und Christus. Der Streit um das wahre Brot', in C. Hattler (ed.), Imperium der Götter (Karlsruhe and Darmstadt, 2013) 243-249. 8 Cf. V. Krech, Wissenschaft und Religion: Studien zur Geschichte der Religionsforschung in Deutschland 1871 bis 1933 (Tübingen, 2002) 263-264; C. Auffarth, “'Licht vom Osten”. Die antiken Mysterienkulte als Vorläufer, Gegenmodell oder katholisches Gift zum Christentum', ARG 8 (2006) 206-226; A. Lannoy and D. Praet (eds), The Christian Mystery. Early Christianity and the Pagan Mystery Cults in the Work of Franz Cumont and in the History of Scholarship, forthcoming.

9 E. Meyer, Ursprung und Anfänge des Christentums, 3 vols (Stuttgart and Berlin, 1921-1923), cf. E. Plümacher, 'Eduard Meyers "Ursprung und Anfänge des Christentums”. Verhältnis zu Fachwissenschaft und Zeitgeist', in W.M. Calder III and A. Demandt (eds), Eduard Meyer (Leiden, 1990) 344-367.

10 M. Mulsow, Prekäres Wissen: eine andere Ideengeschichte der Frühen Neuzeit (Berlin, 2012).

11 M. Neugebauer-Wölk (ed.), Aufklärung und Esoterik (Hamburg, 1999); J. Assmann and F. Ebeling, Ägyptische Mysterien. Reisen in die Unterwelt in Aufklärung und Romantik (Munich, 2011) 7-27.

12 W. Hanegraaff, Esotericism and the Academy (Cambridge, 2012) 212f.

13 J. Assmann: Die Zauberflöte. Oper und Mysterium (Munich, 2005); 'Verwandelnde Erfahrung. Die grossen Mysterien in der Imagination des 18. Jahrhunderts', in A. Bierl and W. Braungart (eds), Gewalt und Opfer. Im Dialog mit Walter Burkert (Berlin and New York, 2010) 343-362; and in Assmann and Ebeling, Ägyptische Mysterien, 162-176. In general, see also E. Hornung, Das esoterische Ägypten (Munich, 1999) 112-132. 
To be fair to Steiner, we should remember that Egyptology was still a young discipline, as it was less than a century since Jean-François Champollion (17901832) had deciphered the hieroglyphs in the early 1820s. Steiner's ideas may have looked less fantastic to his contemporaries than they do to us now. It was only at the moment of Steiner's writing that the leading Egyptologist of the period, Adolf Erman (1854-1937), tried to correct the many popular ideas about Egypt in Germany through a more scholarly approach, just as his pupil James Breasted (1865-1935) did in America. ${ }^{14}$

\section{The Mysteries in the post-Reformation era}

Steiner was only interested in the teachings of the Mysteries, not in their actual rituals. This, too, was not unusual in his day, but it was not true of the first modern study of the ancient Mysteries, which long remained one of the most influential ones, by the Huguenot Isaac Casaubon (1559-1614). ${ }^{15}$ Casaubon's main claim to fame today is as the brilliant philologist who first saw that the ancient Corpus Hermeticum contained words and doctrines alien to its postulated primeval date and thus could not be as old as it was believed to be. This notion of Casaubon as a great discoverer was popularised by the work of Dame Frances Yates (1899-1981) on Hermeticism and it is still cited by Fritz Graf in an important

14 Erman: B.U. Schipper (ed.), Ägyptologie als Wissenschaft. Adolf Erman (1854-1937) in seiner Zeit (Berlin, 2006); Marchand, German Orientalism, 203-206; T. Gertzen, École de Berlin und “Goldenes Zeitalter” (1882-1914) der Ägyptologie als Wissenschaft. Das Lehrer-Schüler-Verhältnis von Ebers, Erman und Sethe (Berlin and New York, 2013). Breasted: J. Abt, American Egyptologist: The Life of James Henry Breasted and the Creation of his Oriental Institute (Chicago and London, 2011).

15 I. Casaubon, De rebus sacris et ecclesiasticis exercitationes XVI (London, 1614) 541-567. On Casaubon, see H. Parenty, Isaac Casaubon helléniste (Geneva, 2009); A. Grafton, Words Made by Words (Cambridge MA and London, 2009) 216-230; idem and J. Weinberg, "I have always loved the Holy Tongue”. Isaac Casaubon, the Jews, and a Forgotten Chapter in Renaissance Scholarship (Cambridge MA and London, 2011). On Mark Pattison, Casaubon's biographer, and the literary representation of Casaubon, see A.D. Nuttall, Dead from the Waist Down (New Haven and London, 2003). R. Gordon, 'Mysterienreligion', in $R G G^{4} 5$ (2002) 1638-1640 has Casaubon write after Jan van Meurs, Eleusinia. Sive, de Cereris Eleusinae sacro, ac festo (Leiden, 1619), but Van Meurs (1579-1639) published his book well after Casaubon's. On the precocious Meursius, see C. Heesakkers, 'Te weinig koren of alleen te veel kaf? Leiden's eerste Noordnederlandse filoloog Joannes Meursius (1579-1639)', in R.J. Langelaan et al. (eds), Miro Fervore. Een bundel lezingen \& artikelen over de beoefening van de klassieke wetenschappen in de zeventiende en achttiende eeuw (Leiden, 1994) 13-26. 
contribution on the Mysteries. ${ }^{16}$ From the 1980s onwards it has become increasingly clear that Casaubon merely improved upon the work of a series of scholars before him and could be credited with the fame of the discovery only because he did not cite his predecessors, ${ }^{17}$ an approach to scholarship that is still popular, as we have seen in Germany in recent years.

Like many of my readers, Casaubon was a workaholic, although perhaps fewer of them will note in their diaries: 'I rose at five: alas, how late!'. ${ }^{18}$ It is therefore not surprising that his last book would be an almost 800 page folio, containing an aggressive attack on Cardinal Cesare Baronio (1538-1607). ${ }^{19}$ The cardinal, no mean worker either, had written a twelve-volume history of early Christianity from the time of Jesus to the Middle Ages, the Annales Ecclesiastici (1588-1607). ${ }^{20}$ As he was born in the century of the Reformation, it is perhaps unsurprising that he composed his work in answer to Protestant attacks on papal claims to spiritual authority and on the antiquity of Catholic institutions and practices, which, as he claimed, went back to the earliest time of Jesus and the Church Fathers. Unfortunately, Baronio was not equal to Casaubon in intellectual sharpness and erudition, and the latter virtually dismantled the first volume of his opponent's Annales by pointing out, time and again, a Baronii hallucinatio, as he called the cardinal's mistakes. ${ }^{21}$

Casaubon wrote during the Protestant-Catholic polemics about the Last Supper, the interpretation of which was a major bone of contention between Catholics and Protestants, as well as of course between Lutherans and Calvinists. It was in a discussion of the Eucharist that Casaubon had collected the ancient references to the Mysteries and the term mystêrion. Casaubon was primarily a philologist and not a historian, a collector rather than an interpreter of his material. Moreover, his assembly of the terminology, characteristics and grades of initiation of the Mysteries concentrated purely on the transfer of pagan rituals and vocabulary to early

16 F. Yates, Giordano Bruno and the Hermetic Tradition (London, 1964); F. Graf, 'Mysteries, Baptism, and the History of Religious Studies. Some Tentative Remarks', in F. Prescendi and Y. Volokhine (eds), Dans le laboratoire de l'historien des religions. Mélanges offerts à Philippe Borgeaud (Geneva, 2011) 91-103 at 100.

17 A. Grafton, Defenders of the Text (Cambridge MA and London, 1991) 145-155; M. Mulsow (ed.), Das Ende des Hermetismus (Tübingen, 2002). The relevant pages of Casaubon on the Corpus Hermeticum have been conveniently reprinted in Mulsow, Das Ende des Hermetismus, 381-396.

18 I. Casaubon, Ephemerides, ed. J. Russell, 2 vols (Oxford, 1850) 1.4.

19 Casaubon, De rebus sacris et ecclesiasticis exercitationes XVI.

20 C. Baronio, Annales Ecclesiastici a Christo nato ad annum 1198, 12 vols (Rome, 1588-1607), cf. C. Pullapilly, Caesar Baronius, Counter-Reformation Historian (Notre Dame, 1975); S. Zen, Baronio storico (Naples, 1994).

21 Casaubon, De rebus sacris, 304; the attacks on Baronio can be easily followed via the index s.v. 
Christianity and did not consider possible Jewish influence on the latter. Nearly a quarter of a century ago, his learned study became the focus of a critical discussion by the leading American historian of religion, Jonathan Smith, in a book with the sub-title On the Comparison of Early Christianities and the Religions of Late Antiquity. ${ }^{22}$ Smith misrepresents Casaubon by stating that the latter defined mystêrion as arcanum (sic) doctrinam, ${ }^{23}$ an expression that is not far from a term that later became popular, arcani disciplina, first used by the Calvinist pastor Jean Daillé (1594-1670) in 1666, ${ }^{24}$ and now most common in German as Arkandisziplin. ${ }^{25}$ In fact Casaubon merely ascribed this explanation to certain Greek grammarians (Graeci grammatici), which shows the breadth of his reading. However, Smith is right to observe that Casaubon's attention to the Mysteries as a whole contrasted with the reductive accounts of later scholars, who treated the Mysteries as being essentially concerned with secret teaching. In the nearly 400 years after Casaubon, our insight into early Judaism, the pagan Mysteries and the early Church has improved considerably, so let us take a fresh look at the possible verbal, ritual and doctrinal influences exerted by the pagan Mysteries on emerging Christianity.

\section{The Mysteries and emerging Christianity}

The long debates of the first half of the twentieth century were summarised and improved by the Englishman Arthur Darby Nock (1902-1963), who was arguably the greatest expert on the relations between Greco-Roman religion on the one

22 J.Z. Smith, Drudgery Divine (Chicago and London, 1990) 55-58.

23 Smith, Drudgery Divine, 57, whereas, of course, Casaubon wrote arcanam doctrinam (542).

24 Smith, Drudgery Divine, 57 n. 10, although misspelling the title, rightly refers to J. Daillé (= Dallaeus), De scriptis, quae sub Dionysii Areopagitae et Ignatii Antiocheni nominibus circumferuntur, libri duo (Geneva, 1666) 142: 'unde certo, ac necessario concludimus totam hanc illius arcani, quarto adulto, et toto quinto saeculo solennem ac notissimam disciplinam primis et Apostolorum proximis saeculis nondum apud nostros fuisse cognitam'. Daillé's terminology was also accepted by Roman Catholics at an early stage, cf. E. Schelmstrate, De disciplina arcani contra disputationem Ernesti Tentzelii dissertatio apologetica (Rome, 1685).

25 For the disciplina arcani, see more recently L. Schindler, Die altchristliche Arkandisziplin und die antiken Mysterien (Tetschen, 1911); O. Perler, 'Arkandisziplin', in RAC 1 (1950) 667-676; D. Powell, 'Arkandisziplin', in TRE 4 (1979) 1-8; C. Jacob, Arkandisziplin, Allegorese, Mystagogie (Frankfurt, 1990), to be read with the review by A.M. Ritter, Theol. Ltz. 119 (1994) 250-252; F. Graf and W. Wischmeyer, 'Arkandisziplin', in $R G G^{4}$ (1998) 743-746 (who date the term to 1686) and, especially, M.-Y. Perrin, 'Arcana mysteria ou ce que cache la religion: De certaines pratiques de l'arcane dans le christianisme antique', in M. Riedl and T. Schabert (eds), Religionen - Die religiöse Erfahrung (Würzburg, 2008) 119-142. 
hand, and both early Christianity and Judaism on the other, in the period from about 1930 to 1960 . Nock was a whiz kid, a Wunderkind. ${ }^{26}$ At the age of twenty, he had already become the annual reviewer for Latin literature in the respected journal The Year's Work in Classical Studies and before he was thirty he was appointed professor at Harvard. In 1952 he published an authoritative review of the question that concerns us here under the title 'Hellenistic Mysteries and Christian Sacraments', ${ }^{27}$ which I, like virtually all scholars after him, will use as the starting point of my discussion.

Nock began with a presentation of the pagan Mysteries in the classical and Hellenistic period; despite some interesting references, the initial part is now mostly outdated due to subsequent discoveries. Yet Nock noted an important difference between the most famous Greek Mysteries, those of Eleusis (Ch. I) and Samothrace (Ch. II.1), and those of Dionysus (Ch. IV.4), Isis (Ch. V.1), Mithras (Ch. V.2) and others. The first, as he observes, were tied to a specific place, but the latter could be practised anywhere. In other words, the second group could and was spread widely over the Mediterranean world, though Nock rightly warned that we should not overestimate the extent of their dissemination.

As regards the verbal parallels, like others before him Nock noted the use of metaphors based on the vocabulary of the Mysteries. More recent research has greatly enlarged our knowledge in this field. It is now clear that Plato had already used a detailed metaphoric terminology, especially in his dialogues Symposium and Phaedrus, that sometimes reflected the Orphic-Bacchic Mysteries but was mainly inspired by the Eleusinian Mysteries. ${ }^{28}$ In Plato's time such metaphors must still have been striking, though Aristophanes had already made use of Mystery metaphors in his Clouds $(143,258)$. This metaphoric use of Mystery terminology was probably an innovation of the Sophists. ${ }^{29}$ A part of their Selbstinszenierung, which has recently been studied in a fine contribution by Martin

26 On Nock, see the obituaries by A.-J. Festugière, Rev. Arch. 1 (1963) 203-205; M.P. Nilsson, Gnomon 15 (1963) 318-319 and H. Chadwick and E.R. Dodds, JRS 53 (1963) 168-169 and Z. Stewart et al., 'A Faculty Minute: Arthur Darby Nock', HSCP 68 (1964) xi-xiv; note also W.M. Calder III, 'Harvard Classics 1950-1956', Eikasmos 4 (1993) 39-49 at 41-42 and his Men in their Books (Hildesheim, 1998) 233-234; G. Casadio, 'Ancient Mystic Religion: the Emergence of a New Paradigm from A.D. Nock to Ugo Bianchi', Mediterraneo antico 9 (2006) 485-534; ungenerous, S. Price, 'The Conversion of A.D. Nock in the Context of his Life, Scholarship, and Religious View', HSCP 105 (2010) 317-339.

27 A.D. Nock, Essays on Religion and the Ancient World, 2 vols (Oxford, 1972) 2.791-820.

28 See the bibliography in Chapter I note 5.

29 C. Riedweg, Mysterienterminologie bei Platon, Philon und Klemens von Alexandrien (Berlin, 1987) 69 n. 200, who, in addition to Aristophanes' Clouds, compares Plato Men. 76e, Tht. 155ef, Euthd. 277e2f. 
Hose, was their great oratorical competence and performance. ${ }^{30}$ The use of Mystery metaphors may have attracted them for its suggestion of exclusive access to special knowledge.

The Mystery metaphor also appealed greatly to the Jewish philosopher Philo, a somewhat older contemporary of the apostle Paul. In his prolific work Philo made extensive use of Mystery terminology to argue that the Holy Scriptures, in his case especially the Pentateuch, contained a secret, symbolic meaning that could only be deciphered through allegorical exegesis. It is not surprising therefore that he often calls the Pentateuch hieros logos, the term used by Herodotus and the Orphics for sacred tales connected with the Mysteries (Ch. III.3). However there is no indication that Philo was initiated himself and he hardly ever refers to specific details of the Mysteries. For the most part he uses this predominantly Platonic terminology to make his language rhetorically more attractive and philosophically more profound. ${ }^{31}$

Philo was not the only Jewish scholar to make use of this terminology. In late books of the Septuagint, the most popular Greek translation of the Old Testament, ${ }^{32}$ we do find the term mystêrion, but nearly always with the meaning either of pagan Mystery cults or as a metaphor for secret plans that were not to be betrayed. More generally, the Septuagint seems to avoid the language of the Mysteries or employs it mainly for prohibited Canaanite practices. ${ }^{33}$ There are really only two verses in the Wisdom of Solomon, a book found in Roman Catholic but not Protestant Bibles, which use the term Mysteries in the same metaphorical manner as Philo. This late book, probably dating to about $50 \mathrm{BC}$, states that the ungodly do not know 'the Mysteries of God' (2.22) and, later, 'As for wisdom, what she is, and how she came up, I will tell you, and will not hide Mysteries, mystêria, from you' (6.22). Given Philo's usage and the - admittedly rare - occurrence in the Septuagint, the early Christians, too, may have employed this Mystery terminol-

30 M. Hose, 'Die Erfindung des Experten. Über Sophisten und ihr Auftreten', in T. Fuhrer and A.-B. Renger (eds), Performanz von Wissen (Heidelberg, 2012) 29-47.

31 Riedweg, Mysterienterminologie, 70-115; M. Bockmuehl, Revelation and Mystery in Ancient Judaism and Pauline Christianity (Tübingen, 1990) 77-81; both of these are overlooked by N. Cohen, 'The Mystery Terminology in Philo', in R. Deines and K.W. Niebuhr (eds), Philo und das Neue Testament (Tübingen, 2004) 173-187; C. Auffarth, 'Mysterien (Mysterienkulte)', in RAC 25 (2013) $422-471$ at $443 f$.

32 See most recently T. Rajak, Translation and Survival: The Greek Bible of the Ancient Jewish Diaspora (Oxford, 2011²); S. Kreuzer et al. (ed.), Die Septuaginta - Entstehung, Sprache, Geschichte (Tübingen, 2012).

33 Bockmuehl, Revelation and Mystery, 102; B.L. Gladd, Revealing the mysterion: the use of mystery in Daniel and Second Temple Judaism with its bearing on First Corinthians (Berlin and New York, 2008). 
ogy, as they seem to do in a few passages of the New Testament. ${ }^{34}$ In the Gospels the most interesting passage is Mark 4.11, where Jesus says to his disciples about the parable of the sower, 'To you has been given the secret, mystêrion, of the kingdom of God, but for those outside everything is in parables'. Here Jesus apparently compares his message to a hidden meaning as revealed in Mystery cults to the initiated but not to outsiders. ${ }^{35}$

The apostle Paul, too, occasionally uses Mystery terminology, ${ }^{36}$ but sometimes at key points in his Letters. In the First Letter to the Corinthians he uses mystêrion for his message to them (2.1), and he compares himself and the apostles to the stewards of the mystêria (4.1). In his Letter to the Romans (11.25) he even uses mystêrion for the heart of his message, the key to understanding God's plan. It is noteworthy that he and other, later Christian authors mostly use the word in the singular, whereas of course the Athenians spoke of Mystêria in the plural as the name of a festival (Preface), even though we can find the singular also in second-century AD pagan inscriptions (SEG 6.59.21). Yet there is general consensus among New Testament scholars that the usage of mystêrion does not indicate a serious influence from the Mysteries. Nonetheless, it seems unnecessary to assume with Guy Stroumsa that the rare usage was derived solely from Paul's Jewish background. ${ }^{37}$ Philo and the Book of Wisdom clearly demonstrate that Platonic Mystery metaphors had been appropriated by pagans and Jews alike.

Nock of course noted the near-absence of Mystery terminology in the New Testament, but he overlooked some clear cases of Mystery terminology in Christian authors of the second century. ${ }^{38}$ Let us consider two of these terms. As we saw in our first chapter, at the moment suprême of the Eleusinian Mysteries the

34 For mystêrion in the New Testament and the early Church, see especially G. Bornkamm, 'mystêrion, mueô', in TWNT 4 (1942) 809-834 (with the older bibliography); A.E. Harvey, 'The Use of Mystery Language in the Bible', JThS 31 (1980) 320-336; R. Schulte, 'Die Einzelsakramente als Ausgliederung des Wurzelsakraments', in J. Feiner and M. Löhrer (eds), Mysterium salutis (Einsiedeln, 1973) 46-155 at 70-93; R. Stupperich, 'Mysterium', in Historisches Wörterbuch der Philosophie 6 (Stuttgart, 1984) 263-267; Bockmuehl, Revelation and Mystery; Auffarth, 'Mysterien (Mysterienkulte)', 444-446.

35 Thus, persuasively, Riedweg, Mysterienterminologie, 89 n. 69.

36 Note also Letter to the Philippians 4.11-13: $\mu \varepsilon \mu$ ún $\mu \alpha \mathrm{s}$ and Letter to the Colossians 2.18:

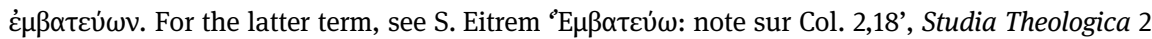
(1948) 90-94; F. Graf, 'Lesser Mysteries - not less Mysterious', in M.B. Cosmopoulos (ed.), Greek Mysteries (London and New York, 2003) 241-262 at 246f.

37 Contra G. Stroumsa, Hidden Wisdom. Esoteric Traditions and the Roots of Christian Mysticism (Leiden, $\left.2005^{2}\right) 4$.

38 See now D.-A. Giulea, 'Seeing Christ through Scriptures at the Paschal Celebration: Exegesis as Mystery Performance in the Paschal Writings of Melito, Pseudo-Hippolytus, and Origen', Orientalia Christiana Periodica 74 (2008) 27-47. 
high priest revealed a huge fire in the dark hall in which the initiands were gathered (Ch. I.3), and this light in the dark returns in many later philosophical writings to denote the highest insight or the seeing of God. Contrary to what Nock states, the term phôtisma/os, literally 'illumination', is already used for Christian baptism in the second-century Christian authors Justin Martyr and Clement of Alexandria. From the context it is clear that a Mystery metaphor is indeed intended. Its use here is not so strange: baptism, too, was a climax, the culmination of the process of incorporation into the Christian church. ${ }^{39}$

Perhaps more interesting is the use of the term symbolon/symbolum, not mentioned by Nock. From the fifth century AD onwards, the Nicene Creed, the Apostles' Creed and all kinds of other Creeds began to be known as symbola in the early Christian church. As the most recent study of the origin of the term notes: 'Because this Apostles' Creed functioned, and in my opinion must have been created, as a declaration pronounced before baptism - either in its interrogative form, to be answered with a simple Credo or by reciting the Apostles' Creed in the first person - the semantic development is no longer a problem: a meaning "baptismal password" or "baptismal declaration" must have developed out of the well-attested profane meaning "password", 40 The derivation from profane passwords, however, overlooks the fact that the term symbolon is already used by Clement of Alexandria to mean a ritual password in the Orphic interpretation of the Mysteries of Demeter and by Plutarch in the context of Dionysiac, but certainly Orphically coloured, Mysteries. ${ }^{41}$ The term has now been found in the sense of 'password' in the fourth-century BC first Orphic Gold Leaf from Thessalian Pherae (OF $493 \mathrm{~F}$ ), the perhaps third-century BC Gold Leaf from Sicilian Entella (OF $475 \mathrm{~F}$ ii.19) and the mid-third-century BC Orphic Gurôb Papyrus (OF $578 \mathrm{~F}, \mathrm{i} .23) .^{42}$ It is highly likely, then, that the term symbolon, which was first used as a baptismal password but later developed into the term for the Creed, derived, ultimately, from the Orphic-Bacchic Mysteries.

39 Justin Martyr Apol. I.61.12; Clem. Alex. Paed. 1.26.1-2, Protr. 12.120.1; cf. G. Anrich, Das antike Mysterienwesen in seinem Einfluss auf das Christentum (Göttingen, 1894) 125-126; Riedweg, Mysterienterminologie, $156 \mathrm{f}$.

40 L. Westra, 'Cyprian, the Mystery Religions and the Apostles' Creed - an Unexpected Link', in H. Bakker et al. (eds), Cyprian of Carthage. Studies in His Life, Language, and Thought (Leuven, 2010) 115-125 at 117 (quote) and 'How Did Symbolum Come to Mean “Creed”?', Studia Patristica 45 (2010) 85-91; see also W. Müri, Griechische Studien (Basle, 1976) 37-44; A. Merkt, 'Symbolum. Historische Bedeutung und patristische Deutung des Bekenntnisnamens', Römische Quartalschrift 96 (2001) 1-36; W. Kinzig, 'Glaubensbekenntnis und Entwicklung des Kirchenjahres', in idem et al. (eds), Liturgie und Ritual in der Alten Kirche (Leuven, 2011) 3-41.

41 Clem. Alex. Protr. 2.15.3; Plut. Mor. 611d.

42 For the symbola of the Mysteries, see also Bernabé ad OF 493.1 F. 
There are thus some verbal parallels between early Christianity and the Mysteries, but the situation is rather different as regards early Christian ritual practice. Much ink was spilled around 1900 arguing that the rituals of baptism and of the Last Supper derived from the ancient Mysteries, but Nock and others after him have easily shown that these attempts grossly misinterpreted the sources. Baptism is clearly rooted in Jewish purificatory rituals, and cult meals are so widespread in antiquity that any specific derivation is arbitrary. ${ }^{43}$ It is truly surprising to see how long the attempts to find some pagan background to these two Christian sacraments have persevered. Secularising ideologies clearly played an important part in these interpretations but, nevertheless, they have helped to clarify the relations between nascent Christianity and its surroundings. ${ }^{44}$

What about doctrinal influence? Here too the search for parallels has been unsuccessful. This is not really surprising, as, to start with, the Mysteries were secret and it thus becomes very difficult to observe possible parallels. More importantly, the main Mysteries, those of Eleusis (Ch. I.3) and Samothrace (Ch. II.1), had no discursive content but limited themselves to showing things. The Orphic-Bacchic Mysteries, on the other hand, did have such content, but the myth of the murder of Dionysus and the incest of Zeus with his daughter (Ch. III.3) could hardly have appealed to the early Christians.

Perhaps the most surprising development in all this has been the gradual disappearance of the comparison between Jesus and the 'rising and dying gods' of the Ancient Near East. As is well noted by Jonathan Smith, in the early twentieth century scholars tended to postulate an archaic pattern of 'dying and rising deities' such as Osiris, ${ }^{45}$ Tammuz (Dumuzi: below), Adonis ${ }^{46}$ and Attis, ${ }^{47}$

43 See now C. Leonhard and B. Eckhardt, 'Mahl V (Kultmahl)', in RAC 23 (2009) 1012-1105; D.E. Smith and H. Taussig (eds), Meals in the Early Christian World (New York, 2012).

44 For good surveys, see J. Hamilton, 'The Church and the Language of Mystery: The First Four Centuries', Ephem. Theol. Lovanienses 53 (1977) 479-494; D.H. Wiens, 'Mystery Concepts in Primitive Christianity and its Environment', in ANRW II.23.2 (Berlin and New York, 1980) 1248-1284; D. Zeller, 'Mysterien/ Mysterienreligionen', in TRE 23 (1994) 504-526 at 519-522; A.J.M. Wedderburn, 'Paul and the Mysteries Revisited', in C. Strecker (ed.), Kontexte der Schrift, 2 vols (Stuttgart, 2005) 2.260-269; Auffarth, 'Mysterien (Mysterienkulte)', 444-446.

45 M. Heerma van Voss, 'Osiris', in $D D D$, 649-651.

46 M. Koortbojian, Myth, Meaning and Memory on Roman Sarcophagi (Berkeley, Los Angeles, London, 1995); S. Ribichini, 'Adonis', in DDD, 7-10; A. Hermary, 'Adonis', in LIMC, Suppl. I (Düsseldorf, 2009) 20-23.

47 For Attis, see most recently G. Casadio, 'The Failing Male God: Emasculation, Death and Other Accidents in the Ancient Mediterranean World', Numen 50 (2003) 231-268; Bremmer, Greek Religion and Culture, the Bible and the Ancient Near East (Leiden, 2008) 267-302; J. Boardman, 'Attis', in LIMC, Suppl. 1 (2009) 123-125; J. North, 'Power and its Redefinitions: the Vicissitudes of 
and the more adventurous among them, such as the famous Sir James Frazer of the Golden Bough, also included the death and resurrection of Christ. ${ }^{48}$ However, more recently scholars have reversed the pattern, claiming that the pagan cults adapted themselves to Christianity. Smith reproaches contemporary scholars of early Christianity as follows:

ignoring their own reiterated insistence, when the myth and ritual complex appeared archaic, that analogies do not yield genealogies, they now eagerly assert what they (the scholars) hitherto denied, that the similarities demonstrate that the Mediterranean cults borrowed from the Christian. In no work familiar to me has this abrupt about-face been given a methodological justification. ${ }^{49}$

This rather curious reproach lumps together virtually a century of scholarship. Why should scholarship not change over such a long period? Given Smith's many criticisms of Protestant scholars, we should note that it was a Catholic, the Fleming Pieter Lambrechts (1910-1974), who initiated this reversal of the fortunes of many a Late Antique cult. ${ }^{50}$ Smith also overlooks the fact that Walter Burkert provided at least the beginning of an explanation for this turning of the scholarly tables. His discussion of these 'dying and rising gods' clearly shows that the basis for the views of Frazer and his contemporaries has been undermined by the continuing publication and analysis of materials from the Ancient Near East. For example, in 1951 a tablet was discovered with the hitherto missing conclusion of the Sumerian myth of Inanna and Dumuzi: instead of his expected resurrection Dumuzi is killed as a substitute for Inanna. ${ }^{51}$ A steady trickle of new artefacts,

Attis', in L. Bricault and C. Bonnet (eds), Panthée: Religious Transformations in the Graeco-Roman Empire (Leiden, 2013) 279-292.

48 For Frazer, see the collection of passages and discussion by Smith, Drudgery Divine, 92-93; note also F. Prescendi, 'Du sacrifice du roi des Saturnales à l'exécution de Jésus', in A. Nagy and ead. (eds), Sacrifices humains: discours et réalités (Paris, 2013) 231-247f. For early protests, see K. Holl, Gesammelte Aufsätze zur Kirchengeschichte, 3 vols (Tübingen, 1928-1932) 2.6-7; A. Lannoy, Het christelijke mysterie: de relatie tussen het vroege christendom en de heidense mysterieculten in het denken van Alfred Loisy en Franz Cumont, in de context van de modernistische crisis (Diss. Ghent, 2012) 229-230 (on studies by M.-J. Lagrange against Frazer around 1920).

49 Smith, Drudgery Divine, 104. I update here my The Rise and Fall of the Afterlife (London and New York, 2002) 53.

50 On Lambrechts, see G. Sanders, 'Pieter Lambrechts', Jaarboek Kon. Ac. België 36 (1974) 370403.

51 W. Burkert, Structure and History in Greek Mythology and Ritual (Berkeley, Los Angeles, London, 1979) 99-101, 105-111; H.-P. Müller, 'Sterbende und auferstehende Vegetationsgötter?', Theol. Zs. 53 (1997) 74-82 and 'Die Geschichte der phönizischen und punischen Religion', J. Semitic Stud. 44 (1999) 17-33; B. Alster, 'Tammuz', in DDD, 828-834; T. Mettinger, The Riddle of Resurrection: Dying and Rising Gods in the Ancient Near East (Stockholm, 2001); F. Wiggermann, 
inscriptions and archaeological monuments has enabled scholars to construct a much more sophisticated view of Late Antiquity than was possible for their colleagues at the beginning of the last century. There is no reason not to see this reversal for what it is: a normal example of progress in scholarship.

In sum, we see that all efforts to derive earliest Christianity from the ancient Mysteries have been unsuccessful. Even the word mystêrion is rarely encountered in the earliest Christian writings. ${ }^{52}$ Yet this is not the end of our story. Before we continue with Christianity, we first have to return to the pagan Mysteries.

\section{The pagan Mysteries in the earlier empire}

As we saw in the previous chapter, the Mysteries of Isis and, especially, those of Mithras became popular in the course of the second century. They were not the only Mysteries that came to the fore at that time. For our purpose I would like to mention briefly three other new Mysteries. ${ }^{53}$ First, when the emperor Hadrian's much younger boyfriend Antinoos drowned in the Nile before the emperor's very eyes in AD 130, several Mystery cults were instituted in memory of him, such as in Antinoopolis, the city that Hadrian founded on the site of the accident, in Klaudiopolis, Antinoos' birthplace in Asia Minor, but also in Mantineia on the Greek mainland, presumably in order to gain privileges from the emperor. ${ }^{54} \mathrm{We}$ know virtually nothing about how this new cult was organised, but it is striking that his memory was celebrated through a Mystery cult.

We are somewhat better informed about our second example: Mysteries created as part of the cult of the emperor. Not surprisingly, these new Mysteries were modelled on the most prestigious Mysteries of the ancient world, the Eleusinian Mysteries. In these imperial Mysteries, which we know only through a few inscriptions, there were singers of hymns, as in Eleusis, as well as a hierophant and a sebastophant, in other words, functionaries who displayed holy objects and the image of the emperor, respectively, perhaps instead of the display

'The Image of Dumuzi', in J.Stackert et al. (eds), Gazing on the Deep. Studies Tzvi Abusch (Bethesda, 2010) 327-347.

52 As observed by C. Mohrmann, Études sur le latin des chrétiens I (Rome, 1961²) 234-236.

53 For a local Mystery cult, see G. Rogers, The Mysteries of Artemis of Ephesos (New Haven and London, 2012)

54 Or. CCelsum 3.36 (Antinoopolis); I. Klaudiopolis 7, 56, 65; Paus. 8.9.7-8; IG V.2 312, 281, cf. L. Robert, A travers l'Asie Mineure (Paris, 1980) 132-138; P. Harland, Associations, Synagogues, and Congregations (Minneapolis, 2003) 296; C.P. Jones, New Heroes in Antiquity: from Achilles to Antinoos (Cambridge MA and London, 2010) 80 n. 11. 
of a statue of Demeter as probably happened in Eleusis (Ch. I.3). There was also heavy eating and drinking, and initiation into these Mysteries was clearly not for free. $^{55}$

We are best informed about my third example, which is perhaps also the most interesting one. From about AD 150 a religious entrepreneur, Alexander of Abonuteichos, was travelling around the ancient world. Like Antinoos, he had started his career as the boyfriend of an older man, in his case a magician. After the latter's death, Alexander set up for himself and toured Greece with a friend, selling his magical tricks. In Macedonia they met an older woman, who was, according to our main source Lucian, 'past her prime but still eager to be charming', and travelling with her they encountered Macedonian women who kept great snakes that were tame and gentle. They bought one, and with its help Alexander set up an oracle in a temple in his home town. Those who wanted advice from this snake god had to put their questions on scrolls of papyrus sealed with wax, which Alexander artfully melted so he could give the right answer. He fashioned a head for the snake, which concealed its real head and was connected to pipes through which someone inside the temple could answer questions, while Alexander himself held the body of the snake in his arms. ${ }^{56}$ Becoming very successful, he finally designed new Mysteries. These were clearly modelled on those of Eleusis but, as he was living in an age of entertainment, he jazzed them up with, as gran finale, the Moon coming down from the roof in the form of a pretty woman who kissed him in front of her husband. Womanising is not alien to religious entrepreneurs, as many an American fundamentalist television preacher has shown. It did not hurt Alexander, and the cult of his snake Glycon outlasted him by a century. ${ }^{57}$

55 H.W. Pleket, 'An Aspect of the Emperor Cult: Imperial Mysteries', HThR 58 (1965) 331-347 (not without some misunderstandings of the traditional Mystery cults); Harland, Associations, 116-119, 128-132; I. Ancyra 8, to be read with the comments of C.P. Jones, JRA 25 (2012) 889.

56 A. Rostad, 'The Magician in the Temple: Historicity and Parody in Lucian's Alexander', C\&M 62 (2011) 207-230.

57 Most recently, G. Bordenache Battaglia, 'Glykon', in LIMC IV.1 (1988) 279-283; A. Chaniotis, 'Old wine in a new skin: tradition and innovation in the cult foundation of Alexander of Abonouteichos', in E. Dąbrowa (ed.), Tradition and Innovation in the Ancient World (Cracow, 2002) 67-85; F. Steger, 'Der Neue Asklepios Glykon', Medizinhistorisches Journal 40 (2005) 1-16; D. Elm, 'Die Inszenierung des Betruges und seiner Entlarvung. Divination und ihre Kritiker in Lukians Schrift “Alexander oder der Lügenprophet”, in ead. et al. (eds), Texte als Medium und Reflexion von Religion im römischen Reich (Stuttgart, 2006) 141-157; A. Petsalis-Diomidis, 'Truly Beyond Wonders'. Aelius Aristides and the Cult of Asklepios (Oxford, 2010) 12-66; R. Gordon, 'Individuality, Selfhood and Power in the Second Century: The Mystagogue as a Mediator of Religious Options', in J. Rüpke and G. Woolf (eds), Religious Dimensions of the Self in the Second Century CE (Tübingen, 2013) 146-172 at 155-161; G. Sfameni Gasparro, 'Oracoli e teologia: praxis oracolare e riflessioni', Kernos 26 (2013) 139-156 (with a list of her many studies of Alexander in the bibliography). 
These examples, which could easily be multiplied, demonstrate that Mysteries, the Eleusinian ones in particular, were an important model for new cults at the time of Christianity's rise. At the same time, it is clear that the Mysteries enjoyed a very high standing not only in religion but also in philosophy. It is remarkable that we find such positive comments about them in historians and philosophers, starting already with Varro in the later first century BC. From Augustine we learn that he had said, 'that there are many truths which it is not useful for the common people to know, and, moreover, that there are many false views which it is expedient that people should take to be true. This, he says, is why the Greeks held their initiations and Mysteries (teletas ac mysteria) in secret and behind closed doors' ${ }^{58}$ According to the philosophers, the Mysteries' hidden wisdom enabled them to escape the superstitious deformation of normal religious cults. For that reason they were greatly appreciated by philosophers in the early centuries of the Roman Empire, as they now saw the Mysteries as the loci of truth par excellence. ${ }^{59}$

\section{Christian reactions to pagan Mysteries}

In the course of the second and later centuries, we note two opposing reactions to the Mysteries from the Christian side. On the one hand, Christians started to combat the Mysteries by trying to expose them and to ascribe their contents to the Devil. On the other hand, as time went on, mainstream Christianity could not escape the high prestige of the Mysteries, and in the course of Late Antiquity we do notice an influence from the Mystery cults on some Gnostic Christian groups as well as on baptism and the Eucharist, the main Christian rituals. Let us therefore conclude by taking a brief look at both developments.

As regards the negative reflections on the Mysteries, we find these already in the writings of one of the earliest Christian apologists, Justin Martyr, who was executed in AD 165. He was a convert and wrote an Apology for the Christian faith around AD 150. In his book Justin comments on the similarities between Christian institutions and pagan ones. ${ }^{60}$ Regarding baptism he says that, having heard of the institution of baptism, demons instigated the pagans to rinse themselves

58 Aug. Civ. 4.31 = Varro, $A R D$ fr. 21, tr. R. Dyson.

59 P. Van Nuffelen, Rethinking the Gods (Cambridge, 2011) 47; add W.C. van Unnik, 'Flavius Josephus and the Mysteries', in M.J. Vermaseren (ed.), Studies in Hellenistic Religions (Leiden, 1979) 244-279.

60 See also J. Pépin, De la philosophie ancienne à la théologie patristique (London, 1986) Chapter VIII ('Christianisme et mythologie. Jugements chrétiens sur les analogies du paganisme et du christianisme', first published in 1981). 
when entering a sanctuary and to wash themselves when leaving. ${ }^{61}$ It is important to note that Justin does not connect baptism with Mystery rites, though modern scholars have often done so. His comparison is also not very persuasive. Pagan purificatory rites with water usually took place at the beginning of a ritual or when entering a sanctuary. ${ }^{62}$ Unlike baptism, it was thus not a unique event that changed a person's position in life by making him the permanent member of a new group. Moreover, the Christians had a preference for 'living water', ${ }^{63}$ which certainly was not always the case in pagan sanctuaries. So why would Justin compare baptism to pagan rituals?

Fritz Graf has attractively argued that the reason was probably because some pagans had pointed out similarities between their rites and those of Christianity. Presumably, these pagans had concluded that there was therefore no reason for the Christians not to participate in pagan rites. It must have been this polemic that induced Justin to compare Christian and pagan rituals. ${ }^{64}$ On the other hand, Tertullian, who lived around AD 200, did actually compare baptism to Mystery cults. Having stated that the pagans 'ascribe power of equal effectiveness to their idols' (as the Christians to God), he proceeds by noting, 'They tell themselves lies, for their waters are barren. In certain rites they are initiated by means of a bath of some Isis or Mithras'. ${ }^{65}$ For him these pagan rituals do display similarities with baptism, but they are simply ineffective, as they lack deeper insight and the presence of the Holy Spirit.

Pagan polemics will also have been in the background of Justin's defence of the Eucharist. When describing its institution by Jesus during the Last Supper, he comments, 'this is exactly what the wicked demons have handed down (paredôkan) by imitation in the Mysteries of Mithras, viz. that bread and a cup of water are placed with certain formulae (epilogôn) in the mystic rites of the initiate'. ${ }^{66}$ With the formulae, which he unfortunately does not quote, Justin clearly alludes

61 Justin Apol. 1.62.1, cf. F. Graf, 'Mysteries, Baptism', 94-95, which partially overlaps with his 'Baptism and Graeco-Roman Mystery Cults', in D. Hellholm et al. (eds), Ablution, Initiation, and Baptism. Late Antiquity, Early Judaism, and Early Christianity, 3 vols (Berlin and New York, 2011) 1.101-118.

62 Parker, Miasma, 20.

63 T. Klauser, Gesammelte Arbeiten zur Liturgiegeschichte, Kirchengeschichte und christlichen Archäologie, ed. E. Dassmann = JAC Erg. 3 (Münster, 1974) 177-184; A. Nestori, 'L'acqua nel fonte battesimale', in Studi in memoria di Giuseppe Bovini, 2 vols (Ravenna, 1989) 2.419-427; S. Ristow, Frühchristliche Baptisterien = JAC Erg. 27 (Münster, 1998) 50-52.

64 Graf, 'Baptism and Graeco-Roman Mystery Cults', 105.

65 Tertullian De baptismo 5.1, tr. E. Evans, slightly adapted.

66 Justin Apol. 1.66.4. Note that paredôkan is a technical term of the Mysteries, cf. Riedweg, Mysterienterminologie, 6-7, where our passage has to be added; Ch. IV n. 79. 
to the words of Jesus, 'This is my body which is given for you: this do in remembrance of me', and, 'This is my blood'. As Fritz Graf notes, this comment of Justin also seems to be a reaction to pagan comments. ${ }^{67}$ Once again, the comparison is not terribly persuasive, but it is true that we see bread rolls and grapes on several Mithraic reliefs. ${ }^{68}$ The cup of water may well have been Justin's interpretation, as water instead of wine was quite normal in the celebration of the early Christian Eucharist. ${ }^{69}$

One may object that a pagan comparison of their Mysteries with the rituals of early Christianity, as suggested by Graf, is only one possibility. Yet we have a very interesting and often neglected pagan testimony for such comparisons, though an indirect one. In AD 248 Origen launched a major attack on the pagan philosopher Celsus, who probably lived around AD 180 and had written a treatise against the Christians, entitled True Doctrine. The book has not survived, but Origen incorporated sizable quotations from it in his own polemical work. Origen relates: 'After having expounded the Mithraic mysteries, Celsus declares that he who would investigate the Christian initiation (teletên) with the aforesaid initiation (teletên) of the Persians, will, on comparing the two together, and on unveiling the (Mysteries) of the Christians, see in this way the difference between them' ${ }^{70}$ Even though Celsus subsequently compared the Mysteries of an obscure Christian group, the Ophites or Snake worshippers, the fact remains that some pagans evidently compared pagan Mysteries with what they considered to be Christian Mysteries. This is also clear from Lucian's pamphlet on Peregrinus, in which he states that Jesus was crucified in Palestine because he had instituted 'that new Mystery cult (teletê)'. ${ }^{71}$

There can indeed be little doubt that elements of the Mysteries had been appropriated by some Christian Gnostic groups. Orthodox Christian polemicists against what they considered to be heretics have given us several examples of this influence, though its actual impact is hard to gauge. It is certainly the case that

67 This is a more subtle approach than the reactions of Alvar, Romanising Oriental Gods, 386-387 and Gordon, 'Mithras', 1001.

68 For bread and grapes, see Merkelbach, Mithras, 132-133; M. Clauss, 'Mithras und Christus', Hist. Zs. 243 (1986) 265-285 at 267-272; E. Sauer, Class. Rev. 57 (2007) 497 (comparing the Mithraic reliefs from Heddernheim, Ladenburg and Dalmatian Konjic).

69 H. Roldanus, 'Die Eucharistie in den Johannesakten', in Bremmer (ed.), The Apocryphal Acts of John (Kampen, 1995) 72-96; M. Daly-Denton, 'Water in the Eucharistic Cup: A Feature of the Eucharist in Johannine Trajectories through Early Christianity', Irish Theol. Quart. 72 (2007) 356-370.

70 Or. CCels. 6.24 and see also 3.59.

71 Luc. Per. 11. For Lucian's noteworthy knowledge of Christianity, see Bremmer, 'Peregrinus' Christian Career', in A. Hilhorst et al. (eds), Flores Florentino (Leiden, 2007) 729-747. 
the word mystêrion in general has a cognitive content ('secret') rather than a ritual one in Gnostic writings, as is also the case in the writings of Mani, the founder of the only world religion that has become extinct. ${ }^{72}$ In various ways the Gnostics seem to have borrowed especially from the Orphics and the Orphic-Bacchic Mysteries, as scholars already began to note around 1900. The relationship between the Gnostics and the Orphics has received renewed attention due to the discovery of the many new Orphic-Bacchic texts that we discussed in our third chapter. $^{73}$

We can only speak of influence with some hesitation, as the Gnostics clearly reworked and appropriated Orphic themes in ways that suited their own systems, but there is a rather striking case in the Gnostic text The (First) Apocalypse of James. This Apocalypse was found among the Nag Hammadi writings, and a second witness has recently turned up in the so-called Codex Tchacos, which gave us the famous Gospel of Judas. ${ }^{74}$ Here we read the following dialogue between the ascending spirit and the guardians, who are described as tax-collectors: 'One of them - because he is a guard - will ask you, "who are you, and where are you from?" You shall say to him, "I am the son, and I am from the Father"' (Codex Tchacos, p. 20). This dialogue, which then develops into a conversation about the pre-existent Father, is clearly related to the one we find in the Gold Leaves, especially those from Crete, where we read the following dialogue between the soul of the dead and the guardians: 'Who are you? Where are you from? - I am a son of Earth and starry Sky'. ${ }^{75}$ There is unmistakably a family resemblance between the two texts in form and function. ${ }^{76}$ Other parallels are less direct, and it is fair to say that the debate about the relationship between Gnosticism and Orphism with its Mysteries is still looking for the right questions rather than already finding persuasive answers.

72 N.A. Pedersen, 'The Term mystêrion in Coptic-Manichaean Texts', in C.H. Bull et al. (eds), Mystery and Secrecy in the Nag Hammadi Collection and Other Ancient Literature: Ideas and Practices (Leiden, 2011) 133-143.

73 Anrich, Das antike Mysterienwesen, 74-105; W. Burkert, Kleine Schriften III (Göttingen, 2006) 45-46, 201; M. Herrero de Jáuregui, Orphism and Christianity in Late Antiquity (Berlin and New York, 2010) 104-107; E. Thomassen, 'Orphics and Gnostics', in J. Dijkstra et al. (eds), Myths, Martyrs, and Modernity: Studies in the History of Religions in Honour of Jan N. Bremmer (Leiden, 2010) 463-473; G. Stroumsa, 'The Afterlife of Orphism: Jewish, Gnostic and Christian Perspectives', Historia religionum 4 (2012) 139-157 at 149-153; Auffarth, 'Mysterien (Mysterienkulte)', 446-447; F. Jourdan, 'Orpheus/Orphik', in RAC 26 (2014) 576-613.

74 R. Kasser and G. Wurst, The Gospel of Judas: Critical Edition (Washington DC, 2007) 119-161.

75 Cf. OF 478-480, 482-483.

76 Thomassen, 'Orphics and Gnostics', 465-467; note for the 'passwords' also Stroumsa, 'The Afterlife of Orphism', 151, quoting the Gospel of Philip in Epiphanius Panarion 26.13.2. 
One thing, though, is clear from these examples from Justin, Tertullian and the Gnostics: pagans did see similarities between their Mysteries and the Christian sacraments, and some Christian groups were not averse to borrowing from the Mysteries. Presumably it is this close proximity that caused Clement of Alexandria, around AD 200, to use a late Hellenistic handbook of the Mysteries (Ch. III.2) to launch a blistering attack on the Mysteries and those who had introduced them into Greece, whom he calls: 'the fathers of their impious myths and deadly superstition, who sowed in human life that seed of evil and ruin: the Mysteries'. Note how the Mysteries are placed here at the end of the sentence as its climax of evil. Clement continues, 'I will prove their orgies to be full of imposture and quackery. And if you have been initiated, you will laugh all the more at these myths of yours which have been held in honour. I proclaim without reserve what has been involved in secrecy, not ashamed to tell what you are not ashamed to worship'. ${ }^{77}$

Yet at the same time Clement's writing is an illuminating example of the ambivalent attitude of the early Christians towards the Mysteries. He rejects actual initiation into Mysteries, but his language is suffused with metaphors from them. In the conclusion of his Exhortation to the Gentiles, in which he attacked the pagan Mysteries so fiercely, we find these ecstatic words: ' $O$ truly sacred Mysteries! O stainless light! My way is lighted with torches, and I contemplate the heavens and God; I become holy whilst I am initiated, but the Lord is the hierophant, and marks his initiate with the seal while illuminating him, ${ }^{78}$ and presents to the Father him who believes, to be kept safe for ever. Such are the Bacchic rituals of my Mysteries'. ${ }^{79}$

Sigmund Freud once coined the expression 'the narcissism of minor differences'. In other words, social and, we should add, religious identities are defended most fiercely against those who are closest to us. That is why civil wars are so cruel and why we all try to defend die feinen Unterschiede (1982) to quote the German title of Bourdieu's La distinction (1979), another reflection on this phenomenon. ${ }^{80}$ There is something of this attitude in the vehemence with which Clement attacks the pagan Mysteries, which were clearly considered to be uncomfortably close to the Christian sacraments.

77 Clem. Alex. Protr. 2.13.5-14.1, tr. W. Wilson. For Clement's attitude to the Mysteries, see H.G. Marsh, 'The Use of mystêrion in the Writings of Clement of Alexandria', JThS 37 (1936) 64-80.

78 Clement often refers to baptism as sealing, cf. J. Ysebaert, Greek Baptismal Terminology (Nimwegen, 1962) 423; Riedweg, Mysterienterminologie, $156 \mathrm{f}$.

79 Clem. Alex. Protr.12.120.1-2, tr. W. Wilson, cf. Auffarth, 'Mysterien (Mysterienkulte)', 447-449.

80 For an interesting discussion of Freud and Bourdieu, see A. Blok, Honour and Violence (Oxford, 2001) 115-135. 
As Christianity became better known in the course of the third century and steadily gained new converts, the threat of the pagan Mysteries receded, and we no longer hear of these comparisons or Christian attacks. At this point, we should not even rule out Christian influence on the pagan Mysteries. The research in this direction has only seriously started in the last decades, and the first interpretations were perhaps too quick to claim Christian influence. ${ }^{81}$ Yet a case like the belief in the resurrection of Attis, which we begin to find in the Mysteries of Cybele and Attis around AD 200, is perhaps an example of such influence of a Christian belief on a pagan Mystery cult. ${ }^{82}$ The resurrection of Jesus himself and his raising of others had made a great impression on the pagan world. References to an apparent death and resurrection start to proliferate in pagan novels already from the Neronian period onwards and several recent studies have suggested that the genre was probably influenced by the Christian Gospel narratives. ${ }^{83}$ In the second century, even pagan magicians started to be credited with the power to resurrect, ${ }^{84}$ and in the third-century biography of the pagan 'saint' Apollonius of Tyana there is a detailed description of the resurrection of a girl that looks very much like it was inspired by Jesus' raisings from the dead in the Gospels. ${ }^{85}$ A Christian influence on the development in the Cybele and Attis Mysteries is thus not to be rejected a priori.

\section{Christian appropriation of the Mysteries in Late Antiquity}

A completely new development suddenly occurred around AD 300. In the course of the first three centuries, Christianity had continuously gained new converts. ${ }^{86}$

81 Cf. Alvar, Romanising Oriental Gods, 417-421; A. Cameron, The Last Pagans of Rome (Oxford, 2011) 151 keeps the possibility open regarding the taurobolium.

82 Hipp. Ref. V.8.22-24 (and 5.9.8); Firmicus Maternus De errore profanarum religionum 3.1, cf. the subtle discussion by P. Borgeaud, La mère des dieux de Cybèle à la vierge Marie (Paris, 1996) 79-88, 146-153, 155. I repeat here in a somewhat revised form a passage from my Rise and Fall, 54.

83 G. Bowersock, Fiction as History: Nero to Julian (Berkeley, Los Angeles, London, 1994); add R. Kany, 'Der Lukanische Bericht von Tod und Auferstehung Jesu aus der Sicht eines hellenistischen Romanlesers', Novum Testamentum 28 (1986) 75-90; V. Schmidt, 'Lukian über die Auferstehung der Toten', VigChris 49 (1995) 388-392.

84 Polemo De physiognomia, pp.160-164 Förster; Luc. Philops. 13 and Alex. 24.

85 Philostr. VA 4.45, cf. Bowersock, Fiction as History, 109f. Note also the often overlooked reference in SHA Aurelianus 24.3.8.

86 For this much discussed process, see most recently Bremmer, The Rise of Christianity through the Eyes of Gibbon, Harnack and Rodney Stark (Groningen, 2010²); C.K. Rothchild and J. Schröter (eds), The Rise and Expansion of Christianity in the First Three Centuries of the Common Era (Tübingen, 2013). 
Their increasing presence in the Roman empire was reflected in the 'conversion' of Constantine after his victory at the Pons Milvius in 312. Suddenly, it seems, the Christians now lost their fear of using pagan terms and within a few years we start to find them using mystêrion/mysterium for baptism and, in particular, the Eucharist with 'Mystery(ies)' even largely displacing the older term eucharistia for the Eucharist. ${ }^{87}$ This development also had an impact on the term for catechism, as can be seen from the title of the catechetical lectures of the late fourth-century Bishop Cyril of Jerusalem, Katêchêses mystagôgikai, 'Catechetical lectures that introduce into the Mysteries'. Evidently catechism now served to introduce the new members into the Mysteries of Baptism, Confirmation and the Eucharist. Church Fathers now spoke of 'participating in the Mysteries' when meaning baptism or the Eucharist. ${ }^{88}$ At the beginning of the Eucharist a deacon now called out 'the doors, the doors', ${ }^{89}$ clearly meaning that they should be closed to those who were not allowed to participate. The cry of course recalls the beginning of the Orphic theogony, where it is said, 'close the doors, o profane' (Ch. III.2), and it is this secrecy that led to the already mentioned term Arkandisziplin ( $\S 2$ ). The Church Fathers even talked about the Eucharist as daidouchia and epoptia, ${ }^{90}$ the first meaning 'illumination by torches', the daidouchos being an important official of the Eleusinian Mysteries, and the second meaning 'Viewing', the highest degree of initiation at Eleusis (Ch. I). They also used the terms phrikôdês and

87 Eus. DE 1.10.32 (mystêrion), 3.4.48 (mystai), 4.7.1 (mystagôgos), cf. most recently E.J. Yarnold, 'Baptism and the Pagan Mysteries', Heythrop Journal 13 (1972) 247-267; M. Wallraff, 'Von der Eucharistie zum Mysterium. Abendmahlsfrömmigkeit in der Spätantike', in P. Gemeinhardt and U. Kühneweg (eds), Patristica et Oecumenica. Festschrift für Wolfgang Bienert zum 65. Geburtstag (Marburg, 2004) 89-104 (to which I am indebted), overlooked by A. Weiss, 'Vom offenbarten Geheimnis zur partiellen Verheimlichung: die Aussendarstellung der frühen Christen', in B. Streck (ed.), Die gezeigte und die verborgene Kultur (Wiesbaden, 2007) 125-143; D.L. Schwarz, 'Keeping Secrets and Making Christians: Catechesis and the Revelation of the Christian Mysteries', in P. Townsend and M. Vidas (eds), Revelation, Literature, and Community in Late Antiquity (Tübingen, 2011) 131-151 (unsatisfactory).

88 Eucharist: John Chrysostom Cat. Bapt. 3.16, 17 (ed. Wenger, SC 50); Cyril of Jerusalem Cat. myst. 4.1, 5.20, 23 (ed. Piédagnel, SC 126); John Chrysostom De paenitentia 6 (= PG 49.323). Baptism: Greg. Naz. Or. 40.45; John Chrysostom Cat. bapt. 2.17, also John Chrysostom Adv. Iud. 4.7 (= PG 48.882), De sanctis martyribus (= PG 50.650), Ep. ad Olymp. 10.3 (ed. Malingry, SC 13bis); Cyril, Cat. Myst. 1.1; Socrates HE 5.19.9; Theodoret Hist. rel. 26.13.

89 Const. Apost. 8.11.11 (ed. Metzger, SC 336); S. Parenti and E. Velkovska, L'Eucologio Barberini gr. 336, 2 vols (Rome, 1995-2000) 1.11. For the function of late antique Christian church doors, see M. Wallraff, “'Ego sum ostium”: Kirchenportale und andere Türen im antiken Christentum', Theol. Zs. 62 (2006) 321-337.

90 Daidouchia: Hesychius of Jerusalem Hom. pasch. 1 (ed. Aubineau, SC 187). Epoptia: Ps.Dion. Areop. EH 3 A.B. 
phriktos - used by Plato to describe the shuddering of the Eleusinian initiate (Ch. I.3) - to describe the experience of the Eucharist. ${ }^{91}$ Among the Montanists, mystês even seems to have been the title of hermits. ${ }^{92}$

At the same time, we should also note transformations in the actual liturgy. Whereas earlier Christian theologians, such as Irenaeus and Tertullian, had declared that Christian teachings were public and taught in public, we now hear a different note. 'We do not talk to pagans about the Mysteries of the Father, Son and Holy Ghost nor do we speak openly about the Mysteries in front of the catechumens', says Cyril (Cat. 6.29), and Athanasius writes, 'We ought not then to parade the holy Mysteries before the uninitiated, lest the pagans in their ignorance mock them, and the catechumens being over-curious be offended'. ${ }^{93}$ Ambrosius even writes, 'the season now warns us to speak of the Mysteries, and to set forth the purport of the sacraments, which if we had thought it well to teach before baptism to those who were not yet initiated, we should be considered rather to have betrayed than to have portrayed the Mysteries'. ${ }^{94}$ In other words, the sacraments had nearly reached the same status as the ancient Eleusinian Mysteries, which could only be made public at risk of capital punishment (Ch. I.4). ${ }^{95}$

With these Church Fathers we have arrived at the end of the fourth century. The theologians had opposed the Mysteries while avidly appropriating their language and secrecy, but Christian rulers were much more radical: Emperor Theodosius I closed the Eleusinian sanctuary in AD 392. The last hierophant was a man 'who held the rank of Father in the Mysteries of Mithras'. ${ }^{96}$ The accumulation of positions in Mysteries had become fairly normal in Late Antiquity, but apparently more for prestige than out of piety. ${ }^{97} \mathrm{~A}$ few decades after these measures we no longer hear of pagan Mysteries in antiquity. The ancient rituals that had existed for more than a thousand years had been unable to resist the powerful hand of the triumphant Christian church. Yet traces of their one-time existence survive in the vocabulary and ritual of the Christian tradition, although

91 Cyril of Jerusalem Cat. myst. 5.4.9; John Chrysostom Hom. 23 in Eph. (PG 62.165), Hom 25 in Eph. (PG 57.331); Lampe s.v. phrikôdês, phriktos, cf. Riedweg, Mysterienterminologie, $64 \mathrm{f}$.

92 P. Lampe, 'Paulinos Mystes', in H.M. Schellenberg et al. (eds), A Roman Miscellany. Essays in honour of Anthony R. Birley on his Seventieth Birthday (Gdansk, 2008) 49-52.

93 Athanasius Apologia contra Arianos, 1.11.

94 Ambrosius De mysteriis 1.2.

95 For the development, with many examples, see Perrin, 'Arcana mysteria ou ce que cache la religion' and 'Norunt fideles. Silence et eucharistie dans l'orbis christianus antique', in N. Bériou et al. (eds), Pratiques de l'eucharistie dans les églises d'orient et d'occident, 2 vols (Paris, 2009) 2.737-762.

96 Eun. VS 476.

97 Cameron, The Last Pagans of Rome, 152-153, where this example has to be added. 
more in the Orthodox East than in the West, and we should not forget that our word 'sacrament' was also used by the Roman Christians for the Mysteries. ${ }^{98}$ In the end, in some way, those ancient Mysteries are still amongst us.

\section{Conclusions}

Looking back on this chapter, it is clear that study of the relationship between the ancient Mysteries and early Christianity has been greatly stimulated by religious polemics. Debates in the aftermath of the Reformation initiated the comparison of the Mysteries with the rituals of the emerging Church. The debates between secularising and more orthodox scholars around 1900 laid the foundations for modern studies by creating a new category, the so-called 'Mystery religions', which were supposedly an influence on, or even a threat for, early Christianity (see Preface).

Modern research, on the other hand, has shown that the constructions of scholars around 1900 were ideologically motivated and were wrong in three important respects. First, there was no such category as 'Mystery religions' but only Mystery cults; the cult of Mithras was, perhaps, the only more-or-less exclusive Mystery cult, whereas other divinities were also worshipped outside their own Mystery cults. Second, these cults were not 'Oriental' religions, as Cumont claimed, but properly Greco-Roman, albeit with some exotic tinges (Ch. V.3). Thirdly, these cults had virtually no impact on the emergence of Christianity nor were they all interested in the afterlife (see Preface).

There never was a flood of 'Oriental religions', as suggested, once again, by Cumont. As we have seen, there were only a few Mystery cults of Isis, and although the number of followers of Mithras in the West was considerable, it should not be overstated. As far as numbers are concerned, Mystery cults never posed a serious threat to emerging Christianity. There are only a few possible references to pagan Mystery cults in the New Testament, which should not surprise us, as interest in the Mysteries flourished most in the second century AD. It is in that period that we start to notice a shared interest by both pagans and Christians in the Mysteries. Pagans seem to have been struck by similarities, but Christians stressed the differences.

The fact that initiation into the Mysteries could be a costly affair and that the Mithras cult was limited to males meant that pagan Mysteries were no competi-

98 Mohrmann, Études sur le latin des chrétiens I, 233-244; Auffarth, 'Mysterien (Mysterienkulte)', 449-451 (with recent bibliography). 
tion for Christianity on the religious market, as the latter always received young and old, rich and poor, male and female into its fold..$^{99}$ Moreover, unlike the Mysteries, Christianity was not esoteric but at first openly proclaimed its message, which was clear to all.

Finally, in our ecumenical times we no longer debate dogmatic points of difference with any intensity, and the question of whether we are believers or agnostics should no longer prevent us from agreeing on the circumstances of the emergence of Christianity. Yet the secretive character of the ancient Mysteries continues and will continue to fascinate. Their emphasis on light and darkness, their promises of happiness in this life and the next, and their experiences of agony and ecstasy keep touching a nerve in the modern mind. My book may not have solved the secrets of the Mysteries or cracked their secret codes, but I do hope that I have succeeded in making these age-old Mysteries just a little bit less mysterious. ${ }^{100}$

99 Cf. Bremmer, 'The Social and Religious Capital of the Early Christians', Hephaistos 24 (2006) 269-278.

100 This chapter has profited from a careful reading by Ton Hilhorst and also from audiences in Munich, New York (Institute for the Study of the Ancient World: 2012), Montréal, Ottawa, Princeton, Fort Worth, Harvard, New York (Fordham), Mainz (2013) and Erfurt (Max Weber Kolleg: 2014). 